\title{
Analysis of the risk factors related to the immune humoral anti- Anaplasma marginale in dairy cattle
}

\section{Análise dos fatores de risco relacionados à resposta imune humoral anti-Anaplasma marginale em vacas de leite}

\author{
Jenevaldo Barbosa da Silva ${ }^{1 *}$; Adivaldo Henrique da Fonseca ${ }^{2}$
}

\begin{abstract}
Anaplasma marginale is the most prevalent pathogen of cattle transmitted by ticks in the world. This study aimed to evaluate the risk factors for anaplasmosis in dairy cattle. Fifty dairy cattle from the herd of Empresa de Pesquisa Agropecuaria do Estado do Rio de Janeiro were selected by proportional stratified sampling. The risk factors evaluated were: physiological state, race pattern, number of lactations, milk production, infestation by Rhipicephalus microplus and animal density. Antibody activity against $A$. marginale was determined using the indirect enzyme-linked immunosorbent assay. The percentual values of seroprevalence for A. marginale were submitted to $\chi^{2}$ test, and the level of minimum significance, to keep a factor in the model of logistic regression, was fixated in 5\%. It was observed that pregnancy and lactation influenced significantly $(\mathrm{p}<0.05)$ in the seropositivity of the animals. Bos indicus animals had 5.21 times more chances of being seropositive than B. taurus animals. Primiparous female had $88 \%$ more chances of being seropositive than pluriparous female. Animals with high milk production were $63 \%$ more positive than low production animals. When infested by ticks the animals had 39\% more chance of being seropositive to A. marginale. Bos indicus animals presented 5.21 times more chance of being seropositive than B. taurus animals. Primiparous females presented $88 \%$ more chance of being seropositive than the pluriparous ones. High milk production animals were $63 \%$ more positive than the low production ones. When infested by ticks the animals had 39\% more chance of being seropositive to A. marginale. High density grazing provided for the animals 3.2 times more chances of being seropositive than low density ones. The herd was classified as erratic to A. marginale, even being placed in a steady enzootic area.
\end{abstract}

Key words: Anaplasma marginale, immunodiagnostic, postpartum, prevalence

\section{Resumo}

Anaplasma marginale é o mais prevalente patógeno de bovinos transmitido por carrapatos em todo o mundo. Este estudo objetivou avaliar os fatores de risco para anaplasmose em vacas de leite. Foram selecionadas por amostragem estratificada proporcional 50 vacas do rebanho da Empresa de Pesquisa Agropecuária do Estado do Rio de Janeiro. Os fatores de risco avaliados foram: estado fisiologico, padrão racial, número de lactações, produção leiteira, infestação por Rhipicephalus microplus e densidade animal. A atividade de anticorpos contra Anaplasma marginale foi determinada utilizado o Ensaio de Imunoadsorção Enzimático Indireto. Os valores percentuais de soroprevalêcia para $A$. marginale foram submetidos ao teste $\chi 2$, sendo que o nível de significância mínima para manter um fator no modelo de regressão logística foi fixado em $5 \%$. Observou-se que, tanto a gestação quanto a lactação influenciaram significativamente $(\mathrm{p}<0.05)$ na soropositividade dos animais. Animais Bos indicus apresentaram 5,21

\footnotetext{
${ }^{1}$ Discente de Doutorado da Faculdade de Ciências Agrárias e Veterinária, FCAV/UNESP, Jaboticabal, SP. E-mail: jenevaldo@ hotmail.com

${ }^{2}$ Prof. da Universidade Federal Rural do Rio de Janeiro, UFRRJ, Seropédica, RJ. E-mail: adivaldofonseca@yahoo.com.br

* Author for correspondence
} 
vezes mais chance de serem soropositivos do que animais $B$. taurus. Fêmeas primíparas apresentaram $88 \%$ mais chance de serem soropositivos do que fêmeas pluríparas. Animais com alta produção leiteira foram $63 \%$ mais positivos do que animais de baixa produção. Quando infestados por carrapatos os animais possuiam $39 \%$ mais chance de serem soropositivos para $A$. marginale. Pastejo sob alta densidade proporcionou aos animais 3,2 vezes mais chances de serem soropositivos do que baixa densidade. $\mathrm{O}$ rebanho foi classificado como instável para A. marginale, mesmo estando localizado em uma área de estabilidade enzoótica.

Palavras-chave: Anaplasma marginale, imunodiagnóstico, periparto, prevalência

\section{Introduction}

Anaplasma marginale is the most prevalent bovine pathogen transmitted by ticks all around the world, existing in six continents and being responsible for high morbidity and mortality in warm, subtropical and tropical regions (PALMER, 1989). The disease is endemic in Latin America, where the main vector is $R$. microplus tick (GUGLIELMONE, 1995; VIDOTTO et al., 1998). The seroprevalence of $A$. marginale varies widely between the countries in Americas and the variability of these taxes contributes for the development of geographic steady regions.

In Brazil, the relation between the population of $R$. microplus ticks and bovine anaplasmosis creates two epidemiologic situations: the first one is observed in the regions where there is a seasonal fluctuation in the population of vectors that may be due to climatic conditions or because inadequate strategies in the control of ectoparasites (ARAÚJO et al., 2003). In these conditions, when the animals stay for a long time without contact with A. marginale, and then become infected, they can presented an accurate clinic disease with high taxes of mortality. In these cases the situation is called enzootic instability (RIBEIRO et al., 1984). The second situation occurs in endemic areas, where the vector population is present all over the year. In these regions the animals have more resistance to infection because they develop immunity in the first months of life while being infected by $A$. marginale when they are still protected by colostrum (ARAÚJO et al., 2003). This situation happens in enzootic steady areas where disease occurrences and high taxes of mortality are not usual.
The epidemiologic situation of the bovine anaplasmosis in the majority of Brazilian regions is of endemic stability (ARAÚJO et al., 1998). However, seroepidemiological studies have proved relevant variations in prevalence with instability areas, where ecologic and climatic factors do not help the development of $R$. microplus vector and of hematophagous dipterous spreader of $A$. marginale (SOUZA et al., 2000). In this context the aim of the study were the evaluation of risk factors to anaplasmosis and endemically characterize a property of dairy cattle in the municipality of Seropédica, Rio de Janeiro State-Brazil.

\section{Materials e Methods}

The field activities were conducted in 2008 and 2009, in the dairy cow section at the Seropédica Experimental Station, which belongs to the Agricultural and Livestock Research Company of the State of Rio de Janeiro (Empresa de Pesquisa Agropecuaria do Estado do Rio de Janeiro; PesagroRio), located in the Rio de Janeiro Metropolitan microregion (latitude $22^{\circ} 45^{\prime} \mathrm{S}$, longitude $43^{\circ} 41^{\prime} \mathrm{W}$ and altitude 33 meters).

To analyze risk factors, the animals were selected and categorized according to proportional stratified sampling, and 84 dairy cattle were randomly selected in this manner. Among these, 44 dairy cattle gave birth during the rainy seasons (spring and summer) and 40 during the dry seasons (fall and winter).

Among the dairy cattle evaluated, 20 were pure Bos taurus (Holstein), 28 were half-blood F1 
through crossbreeding $(1 / 2 B$. taurus $\mathrm{x} 1 / 2 B$. indicus $)$, 21 were Girolando $(5 / 8$ B. indicus x $3 / 8$ B. taurus $)$ and 15 were pure Bos indicus (Gir). Regarding the number of lactations, 20 dairy cattle were at their first lactation, 25 at the second lactation, 24 at the third lactation and 15 at the fourth or subsequent lactation. In the milk production evaluation, the dairy cattle were classified according to their annual production. In the herd evaluated, 27 dairy cattle with milk production lower than $1500 \mathrm{~kg}$ were classified as low-production animals, 37 with milk production between 1500 and $3000 \mathrm{~kg}$ were classified as having moderate milk production, and 20 dairy cattle with production higher than 3000 $\mathrm{kg}$ were classified as high-production animals. To quantify the annual milk production, the study took into consideration 300 days of the year.

The animals were classified in four categories concerning to the level of infestation by $R$. microplus: absence of adult ticks, nymphs and larvae; slight infestation (among 1 and 10 tick engorging and few larvae and nymphs); average infestation (among 11 and 30 tick engorging and average quantity of larvae and nymphs, high infestation (above 31 tick engorging and many larvae and nymphs. In accordance with the routine management procedure at the experimental station, the pregnant dairy cattle were kept in an area of Brachiaria decumbens grass at an animal density of $5 \mathrm{AU} /$ ha for the 30 days before calving. After calving and for the first four weeks of lactation, the animals were kept on $B$. decumbens and Panicum maximum pasture at an animal density of $3 \mathrm{AU} / \mathrm{ha}$.

The sample collections of blood serum were done monthly in empty, dry and latent dairy cattle. There were two samplings in each group totalizing 600 samples, being 200 samples by group. However during peripartum the sampling was done weekly. During peripartum samplings were done 5 weeks before labor, in the week of labor and in the 5 weeks of postpartum, totalizing 550 samples.

Antibody activity against $A$. marginale was determined using the indirect enzyme-linked immunosorbent assay (iELISA) according to Machado et al. (1997) for Babesia bovis, adapted for A. marginale. As positive controls bovine serum was used and kept with high quantity of antibodies anti-A.marginale and as negative controls serologically negative calf serum was used. Total antigen of $A$. marginale with concentration at 12 $\mu \mathrm{g} / \mathrm{ml}$ was used. The reading was done on ELISA reader in a wave length of $405 \mathrm{~nm}$.

The immunological activity of each serum was calculated by determining the sample to positive serum ratio $(\mathrm{S} / \mathrm{P})$ at each dilution, considering positive and negative sera as reference. $\mathrm{S} / \mathrm{P}$ values were grouped into ELISA levels (EL), which ranged from 0 (lowest level) to 9 (highest level). The subsequent levels were determined by increment of $35 \%$ as described by Wilson et al. (1984) for the Newcastle system.

For the effect of area classification Mahoney and Ross (1972) criteria were used, that classified as enzootic stability the areas whose herd have antibodies frequency above $75 \%$, areas of enzootic instability, those ones with frequencies inferior to $75 \%$ and marginal ones whose frequencies are close to the limit.

A qui-square or Fischer's exact tests were used to determine significant differences in percentages of positive results. Variables that were significantly associated with high/low herd seroprevalence at a with $p$-value $\leq 0.20$ in a bivariable screening model were retained for further evaluation in multivariable models. The operational procedures were done using the R Foundation statistical computing software, version 2.12.2 (2011).

\section{Results}

It was observed absorption of $1.09 \pm 0,132$ to the positive controls $(n=15)$ and $0.131 \pm 0,017$ to the negative controls $(n=15)$. The titles of antibodies against $A$. marginale from dry, pregnant, during peripartum and lactating cow serums, kept in areas 
infested by Rhipicephalus microplus, tested by iELISA are distributed in NE in Table 1.

The prevalence of $A$. marginale was of $30 \%$ and $35 \%$ in dry and pregnant dairy cattle respectively. During peripartum it was observed a significant reduction of serum prevalence $(20 \%)$, being in the following period, lactation, the seropositivity raised substantially to $60 \%$. These results demonstrate that during the whole reproductive cycle the herd was epidemiologically instable to $A$. marginale.

The results related to univariate analysis to the evaluated extracts as risk factors associated to the frequency of against A. marginale antibodies are shown in Table 2.

Table 1. Classification of the test serum S/P (sample/Positive) in EL (ELISA Levels) varying from 0-9 in cattle naturally infected with Anaplasma marginale, Pesagro-Rio, 2008-2009.

\begin{tabular}{lccccc}
\hline \multirow{2}{*}{ EL } & \multirow{2}{*}{ A/P } & \multicolumn{4}{c}{ \% sample for levels ELISA (EL) } \\
\cline { 3 - 6 } & $0.000-0.165$ & 65 & Pregnancy & Peripartum & Lactation \\
\hline 0 & $0.166-0.223$ & 23 & 44 & 101 & 20 \\
1 & $0.224-0.301$ & 32 & 22 & 30 & 25 \\
2 & $0.302-0.406$ & 20 & 30 & 19 & 12 \\
3 & $0.407-0.548$ & 25 & 18 & 12 & 41 \\
4 & $0.549-0.740$ & 16 & 14 & 12 & 33 \\
5 & $0.741-0.999$ & 12 & 6 & 6 & 12 \\
6 & $1.000-1.350$ & 3 & 6 & 2 & 18 \\
7 & $1.351-1.820$ & 2 & 2 & 0 & 9 \\
8 & $>2.457468$ & 2 & 3 & 0 & 6 \\
\hline 9 & & & & & \\
\hline
\end{tabular}

$\mathrm{EL}=$ Elisa levels; $\mathrm{S} / \mathrm{P}=$ Absorbance sample

Source: Elaboration of the authors.

Table 2. ELISA absorbance of sera from dairy cattle naturally infected with Anaplasma marginale, Pesagro-Rio, 2008-2009.

\begin{tabular}{lcccccc}
\hline Risk factors & $\mathrm{N}$ & $\mathrm{P}(\%)$ & $\chi^{2}$ & OD & $P$-valor & IC95\% \\
\hline Phsiological state & & & & & & - \\
$\quad$ (1) Peripartum* & 880 & $20 \%$ & - & - & - & {$[0.42-0.86]$} \\
(2) Dry & 200 & $30 \%$ & 8.6 & 0.61 & 0.003 & {$[0.34-0.68]$} \\
(3) Pregnant & 200 & $35 \%$ & 19 & 0.48 & 0.000 & {$[0.12-0.38]$} \\
(4) Lactation & 200 & $60 \%$ & 38 & 0.22 & 0.000 & \\
\hline
\end{tabular}

* Reference value, $\mathrm{N}=$ number of samples evaluated, $\mathrm{P}(\%)=$ Prevalence of seropositivity for Anaplasma marginale, $\chi^{2}=$ qui-squared, $\mathrm{OR}=$ Odds ratio, IC 95\%= confidence interval

Source: Elaboration of the authors.

The final model of multivariate logistic regression for the frequency of antibodies of $\operatorname{IgG}$ class against $A$. marginale in dairy cattle related to the physiologic state is represented in Table 3.
In the logistic model it was observed that lactating dairy cattle had 5.1 more chances of being serum positive to $A$. marginale than dry dairy cattle, Bos indicus animals had 5.21 more chances than 
$B$. taurus animals. The reproductive experience directly influenced in the seropositivity to $A$. marginale because $1^{\text {st }}$ lactation animals had $88 \%$ more chances of being positive than $2^{\text {nd }}$ lactation ones. Low milk production animals had $63 \%$ more chances of having against $A$. marginale antibodies than high production animals. In addition, low tick infestation animals had 39\% more chances than moderate infestation animals. When kept in high density pasture it was observed that the animals has 3.2 more chances of being seropositive than animals kept in low density.

Table 3. Final multivariable logistic regression model for seroprevalence of antibodies against Anaplasma marginale in dairy cattle, Pesagro-Rio, 2008-2009.

\begin{tabular}{|c|c|c|c|c|}
\hline Factor & Category & $p$-valor & OR & IC $95 \%$ \\
\hline \multirow[t]{4}{*}{ Physiological state } & dry* & - & - & - \\
\hline & Pregnant & 0.009 & 1.94 & {$[1.174-3.231]$} \\
\hline & Peripartum & 0.006 & 0.20 & {$[1.042-1.867]$} \\
\hline & lactantion & 0.000 & 5.10 & {$[3.054-8.532]$} \\
\hline \multirow[t]{4}{*}{ Breed } & B. taurus* & - & - & - \\
\hline & $\mathrm{F} 1$ & 0.108 & 2.69 & {$[0.888-3.235]$} \\
\hline & girolando & 0.000 & 2.96 & [1.634-5.374] \\
\hline & B. indicus & 0.000 & 5.21 & [2.797-9.707] \\
\hline \multirow[t]{4}{*}{$\mathrm{N}^{\circ}$ Lactation } & $1^{\circ}$ lactation* & - & - & - \\
\hline & $2^{\circ}$ lactation & 0.097 & 0.63 & {$[0.371-1.086]$} \\
\hline & $3^{\circ}$ lactation & 0.000 & 0.12 & {$[0.068-0.243]$} \\
\hline & $4^{\circ}$ lactation & 0.000 & 0.14 & {$[0.078-0.265]$} \\
\hline \multirow[t]{3}{*}{ Milk production } & $<1500^{*}$ & - & - & - \\
\hline & $>1500<3000$ & 0.086 & 0.64 & {$[0.392-1.064]$} \\
\hline & $>3000$ & 0.001 & 0.37 & {$[0.208-0.693]$} \\
\hline \multirow[t]{3}{*}{ R. microplus } & low* & - & - & - \\
\hline & medium & 0.053 & 0.61 & {$[0.369-1.007]$} \\
\hline & high & 0.406 & 0.75 & [0.386- 1.469$]$ \\
\hline \multirow[t]{3}{*}{ Stocking density } & low* & - & - & - \\
\hline & medium & 0.982 & 1.18 & {$[0.560-1.889]$} \\
\hline & high & 0.004 & 3.28 & {$[2.528-3.219]$} \\
\hline
\end{tabular}

$\mathrm{OR}=$ Odds ratio, $\mathrm{IC} 95 \%=$ confidence interval

Source: Elaboration of the authors.

\section{Discussion}

The innate and acquired defense mechanisms in bovines are reduced during labor (MALLARD et al., 1998). This reduced answer capacity includes alterations in systemic, physical and metabolic immunity that substantially contributes to the decrease of resistance and the increase of infectious and parasitic diseases in that period. In this study it was observed reduction of the quantity of antibodies during peripartum and lactation. These results clearly showed that in that period the animal were susceptible to anaplasmosis. So in studies of disease risks, in which antibodies are passively transferred by colostrum, peripartum dairy cattle must be considered as a risk group. 
Some studies were done to determine the susceptibility of $B$. indicus and $B$. taurus bovines to infection by $A$. marginale. Parker, Shepherd and Trueman (1985) demonstrated that rickettsia is slightly superior to $B$. taurus in comparison to $B$. indicus, but the clinical signs are not different between the races. In addition it was concluded that serious reactions happened in both races implying that in a field situation zebuine do not present more resistance to anaplasmosis in comparison to the taurine ones. However it was noticed that the quantity of $B$. taurus and B. indicus antibodies significantly varied in all studied groups, demonstrating that taurine animals can be more vulnerable to $A$. marginale due to the lower quantity of circulating antibodies.

Bock, Kingston and De Vos (1999) studied the susceptibility of taurine and zebuine bovines in pasture infested by $R$. microplus infected with an isolated virulent of $A$. marginale. The authors observed that although there was no significant difference between races in resisting to the infection there was a considerable variation in the resistance to $A$. marginale in both races and the mortality was higher in $\mathrm{v} B$. taurus animals. The authors concluded that $A$. marginale could infect both races in their crossbreeding, however it causes considerable loses in B. taurus races.

Concerning to the reproductive experience the observed results in this study are similar to the ones seen by Larson and Hays (1958) and Dixon, Hart and Fouts (1961). According to these authors an important source of variation of the levels of immunoglobulin in colostrum is related to the reproductive experience, considering that primiparous dairy cattle usually produce an inferior quality of colostrum. So first lactation dairy cattle, due to the lower quantity of antibodies passed through colostrum, ending up circulating a higher quantity of immunoglobulin. The low quantity of antibodies in older animals may be credited to the debility of the immune system due to age.
Besser and Gay (1994) observed that high production animals are characterized in general for showing more elevated global levels of IgG in their colostrum than low production animals. In milk dairy cattle due to specialization it was showed that migration of serum immunoglobulin to the mammal glands, during the formation of colostrum, determines a decrease in concentration of this protein in the blood stream, in the last weeks of peripartum (DIXON; HART; FOUTS, 1961). In this study high production dairy cattle had less quantity of circulating antibodies in all physiological phases. These results indicate that, beyond the passive passing of higher quantity of immunoglobulin to colostrum, the genetic for high production may also be associated to the low quantity of antibodies against $A$. marginale.

The increase of $R$. Microplus density was associated to the decrease in risk for the occurrence of anaplasmosis. This tendency of serum conversion risk is probably associated to the increase of the transmission of the agent to the animals from the herd. In the herd by studying the practices of parasite control it results in a low population of the vector maybe insufficient to keep constantly the transmission of $A$. marginale. According to Mahoney and Ross (1972), in this case an unbalance caused by the parasite-host relation due to the infrequent transmission it creates an artificial condition of endemic instability, where seasonally happens clinic cases in the period of maximum activity of the vectors.

According to Swai et al. (2005) in univariate analysis, the number of adult $R$. appendiculatus had significant association with a higher probability of an animal presenting serum conversion to $A$. marginale (coefficient $=0.039$ e $\mathrm{P}<0.01$ ). When this same analysis was done to $R$. microplus it was not observed significant association to this agent. In our study, even after the analysis of logistic regression, the infestation by $R$. microplus is an important risk factor to anaplasmosis. 
This study corroborates to Rodríguez-Vivas et al. (2004) who observed higher seroprevalence to A. marginale in animals kept in density superior to $1 \mathrm{animal} / \mathrm{ha}(\mathrm{OR}=10.94)$. Pérez et al. (1994), considerate that high animal density was the factor the contributed the most for the high seroprevalence of $A$. marginale in studies done in California, South part of New Zealand and Costa Rica. Guglielmone (1995) also observed that A. marginale vectors, including $R$. microplus have a high probability of been fed in susceptible animals and consequently do inoculation of large quantity of inoculum when there is high animal density.

\section{Conclusion}

Not only environmental factors as intrinsic factor are important to the epidemiology of anaplasmosis but also these factors must be analyzed together with other factors such as: kinds of pasture, animal density, vector density and control measure to classify the properties concerning to the risk of occurrence of disease in endemic areas to $A$. marginale.

\section{Acknowledgments}

To the CNPq for the financial support. We are grateful to Rosangela Zacarias Machado for helpful and assistance.

\section{References}

ARAÚJO, F. R.; MADRUGA, C. R.; BASTOS, P. A. S.; MARQUES, A. P. C. Freqüência de anticorpos anti Anaplasma marginale em rebanhos leiteiros da Bahia. Arquivo Brasileiro de Medicina Veterinária e Zootecnia, Belo Horizonte, v. 50, n. 3, p. 243-246, 1998.

ARAÚJO, F. R.; MADRUGA, C. R.; SOARES, C. O.; KESSLER, R. H. Progressos na imunização contra Anaplasma marginale. Pesquisa Veterinária Brasileira, Seropédica, v. 23, n. 4, p. 139-148, 2003.
BESSER, T. E.; GAY, C. C. The importance of colostrum to the health of the neonatal calf. The Veterinary clinics of North America: Food Animal Practice, Oklahoma, v. 10, n. 1, p. 107-117, 1994.

BOCK, R. E.; KINGSTON, T. G.; DE VOS, A. J. Effect of breed on transmission rate and innate resistance of cattle to infection with Babesia bovis and B. bigemina transmitted by Boophilus microplus. Australian Veterinary Journal, Malden, v. 77, n. 2, p. 461-464, 1999.

DIXON, R. L.; HART, L. G.; FOUTS, J. R. The metabolism of drugs by liver microsomes from alloxandiabetic rats. Journal of Pharmacology and Experimental Therapeutics, Bethesda, v. 133, n. 1, p. 7-11, 1961.

GUGLIELMONE, A. A. Epidemiology of babesiosis and anaplasmosis in South and Central América. Veterinary Parasitology, Amsterdam, v. 57, n. 1, p. 109-119, 1995.

LARSON, B. L.; HAYS, R. L. An explanation for bovine parturation edema and treatment with blood protein replacements. Journal of Dairy Science, Champaign, v. 41, n. 1, p. 995-997, 1958.

MACHADO, R. Z.; MONTASSIER, H. J.; PINTO, A. A.; LEMOS, E. G.; MACHADO, M. R. F.; VALADÃO, I. F. F.; BARCI, L. G.; MALHEIROS, E. B. An enzymelinked immunosorbent assay (Elisa) for the detection of antibodies against Babesia bovis in cattle. Veterinary Parasitology, Amsterdam, v. 71, n. 1, p. 17-26, 1997.

MAHONEY D. F.; ROSS, D. R. Epizootiological factors in the control of bovine babesiosis. Australian Veterinary Journal, Malden, v. 48, n. 1, p. 292-298, 1972.

MALLARD, B. A.; DEKKERS, J. C.; IRELAND, M. J.; LESLIE, K. E.; SHARIF, S.; VANKAMPEN, C. L.; WAGTER, L.; WILKIE, B. N. Alteration in Immune responsiveness during the peripartum period and its Ramification on dairy cow and calf health. Journal Dairy Science, Champaign, v. 81, n.2, p. 585-595, 1998.

PALMER, G. H. Anaplasma vaccines. In: WRIGHT, I. G. (Ed.). Veterinary protozoan and hemoparasite vaccines. Washington, 1989. p. 1-29.

PARKER, R. J.; SHEPHERD, R. K.; TRUEMAN, K. F. Susceptibility of Bos indicus and Bos taurus to Anaplasma marginale and Babesia bigemina infections. Veterinary Parasitology, Amsterdam, v. 17, n. 1, p. 205213, 1985.

PÉREZ, E.; HERRERO, M. V.; JIMENEZ, C.; HIRD, D.; BUENING, G. B. Effect of management and host factors on seroprevalence of bovine anaplasmosis and babesiosis in Costa Rica. Preventive Veterinary Medicine, New York, v. 20, n. 1-2, p. 33-46, 1994. 
RIBEIRO, M. F. B.; PATARROYO, J. H. S.; SANTOS, J. L.; FARIA, J. E. Epidemiologia da anaplasmose bovina no estado de Minas Gerais. I - prevalência de anticorpos aglutinantes e fluorescentes na Zona da Mata. Arquivo Brasileiro de Medicina Veterinária e Zootecnia, Belo Horizonte, v. 36, n. 4, p. 425-432, 1984.

RODRÍGUEZ-VIVAS, R. I.; MATA-MENDEZ, Y.; PEREZ-GUTIERREZ, E.; WAGNER, G. The effect of management factors on soroprevalence of Anaplasma marginale in Bos indicus cattle in the Mexican tropics. Tropical Animal Health and Production, Midlothian, v. 36, n. 2, p. 135-143, 2004.

SOUZA, J. C. P.; SOARES, C. O.; SCOFIELD, A.; MADRUGA, C. R.; CUNHA, N. C.; MASSARD, C. L.; FONSECA, A. H. Soroprevalência de Babesia bigemina em bovinos na mesorregião Norte Fluminense. Pesquisa Veterinária Brasileira, Niterói, v. 20, n. 1, p. 26-30, 2000.
SWAI, E. S.; KARIMURIBO, E. D.; OGDEN, N. H.; FRENCH, N. P.; FITZPATRICK, J. L.; BRYANT, M.J.; KAMBARAGE, D.M. Seroprevalence estimation and risk factors for $A$. marginale on smallholder dairy farms in Tanzania. Tropical Animal Health and Production, Midlothian, v. 37, p. 599-610, 2005.

VIDOTTO, O.; BARBOSA, C. S.; ANDRADE, G. M.; MACHADO, R. Z.; ROCHA, M. A. da; SILVA, S. $S$. Evaluation of a frozen trivalent attenuated vaccine against Babesiosis and anaplasmosis in Brazil. Annals of Academic of Science fo New York, v. 849, n. 1, p. 420423, 1998.

WILSON, R. A.; PERROTA JUNIOR, C.; FREY, B.; ECKROADE, R. J. An enzyme-linked immunosorbent assay that measures protective antibody levels to Newcastle disease virus in chickens. Avian Diseases, Jacksonville, v. 28, n. 2. p. 1079-1085, 1984. 